\title{
A COVID-19-járvány hatása a szervadományozásra és -átültetésre Magyarországon 2020-ban
}

\author{
Mihály Sándor dr. ${ }^{1}$ - Egyed-Varga Anita ${ }^{1}$ - Trnka-Szántay Kinga ${ }^{1}$ \\ Deme Orsolya $^{1}$ - Holtzinger Emese ${ }^{1}$ - Nacsa János dr. ${ }^{1}$ - Piros László dr. ${ }^{2}$ \\ 'Országos Vérellátó Szolgálat, Budapest \\ ${ }^{2}$ Semmelweis Egyetem, Általános Orvostudományi Kar, Transzplantációs és Sebészeti Klinika, Budapest
}

\begin{abstract}
Bevezetés: A SARS-CoV-2-világjárvány terjedése drasztikus változásokat okozott a mindennapi betegellátásban, amelyek érintették a szervadományozás és -átültetés területét is, így csökkent az élő és az elhunyt donorokból történő donációk és transzplantációk száma világszerte. Az esetszám csökkenése mellett a transzplantált és egyben immunszupprimált betegek védelme érdekében további biztonsági intézkedéseket kellett bevezetni.

Módszer: A vizsgálat célja a COVID-19-járvány hazai donációs és transzplantációs aktivitásra gyakorolt hatásának kimutatása volt 2020-ban, a megelőző évvel történő összehasonlításban. A magyar eredményeket összehasonlítottuk elsősorban az Eurotransplant, illetve az Európai Unió tagállamainak adataival is.

Eredmények: A lakosságszámra súlyozott, regisztrált COVID-19-fertőzöttség és -halálozás tekintetében nem igazoltunk 2020-ban kiemelkedő eltérést itthon az Eurotransplant-tagállamokhoz képest. A hazai szervdonációs potenciál nem csökkent a vizsgált időszakban, ugyanakkor 38,33\%-kal csökkent az agyhalott szervdonorok száma Magyarországon, míg az Eurotransplantban átlagosan 8,64\%-kal és 23 adatközlő európai országban 17,55\%-kal. Az elhunytból történt szervátültetések száma 29,27\%-kal csökkent, különösen a szív- és a májátültetések esetén. A külföldről kapott szervek száma 21,13\%-kal és aránya 12,34\%-kal emelkedett. Az élő donoros veseátültetések száma nem változott. 2020-ban 25\%-kal kevesebb új beteget regisztráltak, mint 2019-ben, és a várólista-mortalitás 28\%-kal növekedett az előző évhez képest, kifejezetten a veseátültetésre várók között.

Következtetés: A hazai szervátültetési program biztonságos: donoreredetû SARS-CoV-2-átvitel nem történt hazánkban. A szervdonációs potenciál és a COVID-19-járvány mellett a szervdonációs és -transzplantációs aktivitás jelentősen csökkent Magyarországon 2020. márciustól az év végéig. A legtöbb európai országban átmeneti és kisebb mértékű szervdonációs csökkenést regisztráltak. A szervátültetések száma nem csökkent olyan mértékben, mint a donorszám, mert az Eurotransplantból több donorszerv érkezett hazánkba, mint amennyit külföldre küldtünk. Orv Hetil. 2021; 162(23): 890-896.
\end{abstract}

Kulcsszavak: SARS-CoV-2-járvány, COVID-19, szervadományozás, transzplantáció

\section{The impact of the COVID-19 pandemic on organ donation and transplantation in Hungary in 2020}

Introduction: The spread of the SARS-CoV-2 pandemic has resulted in drastic changes in day-to-day patient care, which has also affected the field of organ donation and transplantation, thus reducing the number of donations and transplants from living and deceased donors worldwide. In addition to the reduction in the number of cases, additional safety measures had to be introduced to protect transplanted and implicatively immunosuppressed patients. Method: The aim of the study was to demonstrate the impact of the COVID-19 epidemic on domestic donation and transplantation activity in 2020, compared to the previous year. We also compared the Hungarian results with the data of the Eurotransplant and the European Union member states.

Results: In terms of population-weighted, registered COVID-19 infection and mortality, we did not find a significant difference in Hungary in 2020 compared to the Eurotransplant member states. The national organ donation potential did not diminish in the period under review, however, the number of brain-dead organ donors decreased by $38.33 \%$ in Hungary, while in the Eurotransplant it did by $8.64 \%$ on average and in 23 reporting European countries by $17.55 \%$. The number of organ transplants from the deceased decreased by $29.27 \%$, especially regarding heart and liver transplants. Both the number and the proportion of organs received from abroad increased by $21.13 \%$ and 
$12.34 \%$, respectively. The number of living donor kidney transplants did not change. In 2020, 25\% fewer new patients were registered than in 2019 and the mortality on waiting list increased by $28 \%$ compared to the previous year, especially among those waiting for a kidney transplant.

Conclusion: The national organ transplantation program is safe: donor-derived SARS-CoV-2 transmission did not occur in Hungary. In addition to the organ donation potential and the COVID-19 pandemic, organ donation and transplantation activity decreased significantly in Hungary from March 2020 until the end of the year. Transient and smaller reductions in organ donation rates have been reported in most European countries. The number of organ transplants did not decrease as much as the number of donors, because more donor organs arrived in Hungary from the Eurotransplant than we sent abroad.

Keywords: SARS-CoV-2 pandemic, COVID-19, organ donation, transplantation

Mihály S, Egyed-Varga A, Trnka-Szántay K, Deme O, Holtzinger E, Nacsa J, Piros L. [The impact of the COVID-19 pandemic on organ donation and transplantation in Hungary in 2020]. Orv Hetil. 2021; 162(23): 890-896.

(Beérkezett: 2021. március 31.; elfogadva: 2021. április 4.)

\begin{abstract}
Rövidítések
BNO = Betegségek Nemzetközi Osztályozása; COVID-19 = (coronavirus disease 2019) koronavírus-betegség 2019; CT = (computed tomography) számítógépes tomográfia; ECDC = (European Centre for Disease Prevention and Control) Európai Betegségmegelőzési és Járványvédelmi Központ; ET = Eurotransplant; EU = Európai Unió; PCR = (polymerase chain reaction) polimeráz-láncreakció; $\mathrm{PMP}=$ (per millon population) egymillió lakosra számított adat; RT-PCR $=$ (real-time PCR) valós idejű PCR; SARS-CoV-2 = (severe acute respiratory syndrome coronavirus type 2 ) súlyos akut légúti tünetegyüttest okozó koronavírus-2; UNOS = (United Network for Organ Sharing) az Amerikai Egyesült Államok donorszervallokációs hálózata
\end{abstract}

2019. december elején Wuhan városából, Hupei tartományból (Kína) jelentés érkezett egy ismeretlen eredetû tüdőgyulladással diagnosztizált betegcsoportról [1]. Az új béta-koronavírus típusú kórokozó a SARS-CoV-2 nevet kapta, mely nagy filogenetikus hasonlóságot mutat a 2002-ben Kínában azonosított, SARS-CoV elnevezésú vírussal [2]. Első jelentése óta a SARS-CoV-2 kórokozó által okozott, 2019. évi koronavírus-betegség (COVID-19) világszerte rapid módon terjedt, 2020. március 11-én az Egészségügyi Világszervezet a járványt hivatalosan pandémiává minősítette $[3,4]$.

Magyarországon az első igazolt COVID-19-fertőzött beteget 2020. március 4-én regisztrálták, majd 2020 . március 11 -én kihirdették az országos veszélyhelyzetet. Az első elhunyt beteget 2020. március 15-én regisztrálták itthon [5].

A SARS-CoV-2-világjárvány példátlan sebességgel terjedt az egész világon, így drasztikus változásokat okozott a mindennapi betegellátásban, amelyek érintették a szervadományozás és -átültetés területét is. A járvány azonnali hatásaként súlyosan csökkent mind az élő donoros, mind az elhunyt donorokból történő donációk és transzplantációk száma világszerte [6]. Komoly aggodalomra adott okot, hogy a szervátültetésen átesett betegeknek nagyobb a fertőzésekre való hajlamuk az immunszuppreszszió miatt [7]. A járvány kitörése óta számos esettanulmányt publikáltak, melyek az adott betegpopuláció nagyobb arányú szövődményeire utalnak [8].

A SARS-CoV-2 donorszerv-eredetú átvitelének elkerülése érdekében a potenciális donorok szúrése korán megkezdődött az Eurotransplant (ET) egész területén, így Magyarországon is. A világjárvány kezdetén kérdéses volt, hogy a szervátültetés céljából kórházakba érkező recipiensekre nézve milyen mértékü fenyegetettséget jelent a SARS-CoV-2-fertőzés lehetséges kockázata a perioperatív időszak alatt, továbbá hogy milyen intézkedések bevezetése válhat szükségessé a kockázat minimalizálása érdekében. Első lépésben az élő donoros veseátültetési programok átmeneti felfüggesztése történt meg. Életminőséget javító szervátültetéseket alapos mérlegelés mellett, maximális óvatossággal végeztek, ám az életmentő szervtranszplantációk (szív, tüdő, máj) folytatódtak, mindemellett a donorok és a recipiensek szúrése is megkezdődött (részletes kórtörténet, utazási anamnézis, klinikai leletek, mellkas-CT, SARS-CoV-2-PCRvizsgálat).

A fó akadályt azonban nem a betegbiztonsági kérdések jelentették a szervadományozás és -átültetés terén. Az igazolt fertőzött COVID-19-esetek és ennek következtében kórházi ellátást igénylő esetek számának növekedése miatt az intenzív ellátási területek a COVID19-betegek kezelésére összpontosítottak világszerte, ennek érdekében az erőforrások átszervezésére volt szükség. Ebben a helyzetben egyre nehezebbé vált a potenciális donorok felismerése, jelentése, gondozása, a komplex szervezeti struktúra fenntartása, különösen azért, mert mind a potenciális szervdonorok, mind a transzplantáción átesett betegek ugyanazon egészségügyi erőforrásokra (például intenzív betegellátó kapacitásra) vannak utalva, mint a súlyos állapotú COVID-19fertőzöttek. 


\section{Módszer}

A vizsgálat célja a COVID-19-járvány donációs és transzplantációs aktivitásra gyakorolt hatásának kimutatása, melyhez - a járvány magyarországi márciusi megjelenését is figyelembe véve - a 2020. év adatait elemeztük, összevetve a megelőző év ugyanezen időszakával.

Az elemzést az ET-tagállamokban jelentett, igazolt COVID-19-fertőzöttek és -elhunytak egymillió lakosra számított adatainak összehasonlításával kezdtük.

Vizsgáltuk a donorjelentések számát és változását, a megvalósult donációk számát, arányát és változását országosan és intézményenként, a többszervi donorok arányának változását, az egy donorból eltávolított szervek átlagos számának változását, továbbá ennek befolyásoló hatását a szervátültetések számára szervenként. Ez utóbbit az ET-együttmúködés keretei között külföldről kapott donorszervek száma és annak változásai is befolyásolják. A donációs és transzplantációs esetszámok változásait összehasonlítottuk az Eurotransplant Nemzetközi Szervcsere Szervezet tagállamainak adataival is, illetve a donorszám tekintetében összehasonlítást végeztünk az EU-tagállamok és az Egyesült Királyság adataival is.

Vizsgálatunk tárgya, hogy milyen mértékben befolyásolta a COVID-19-járvány a magyarországi donációs és transzplantációs aktivitást, továbbá hogy a járványügyi intézkedések közül melyek azok, amelyeket hosszabb távon szükséges és célszerü alkalmazni. Tanulmányoztuk, hogy a kapacitás átcsoportosítása lassította-e a végstádiumú szervelégtelen betegek várólistára kerülésének esélyeit, befolyásolta-e a listázott betegek transzplantációs esélyeit, illetve a várólistamozgás (új betegek száma, elvégzett és elmaradt átültetések száma) hogyan befolyásolta a várólista-mortalitást.

\section{Eredmények}

\section{Fertözöttségi adatok}

AZ ECDC heti bontásban közölt adatai alapján az igazolt COVID-19-fertőzöttek száma tekintetében Magyarország 2020. március 19-tôl szeptember 28-ig a 8 . helyen állt az ET 8 tagországa között, majd ezt követően az év végéig a 7 . helyre került. A magyarországi igazolt fertőzöttek egymillió före eső száma kevesebb mint a fele volt a legmagasabb luxemburgi adatnak [9].

Az egymillió lakosra jutó, COVID-19 okozta halálozás tekintetében az év végén Belgium állt az 1 . helyen. Magyarország 2020. március 19-én a 8 ET-tagállam között még a 8. helyen állt a lakosságszámra súlyozott COVID-mortalitás tekintetében, majd 2020. március 23-tól a 7., június 3-tól a 6., augusztus 11 -tôl újra a 7., szeptember 15-től a 6., október 13-tól az 5., október 20-tól a 4., november 10-tôl az 5. lett újra, azután december 8-tól az év végéig a 3. helyre került (1. táblázat) [9].
1. táblázat |Az igazolt COVID-19-fertőzöttek száma és mortalitása az Eurotransplant tagállamaiban 2020. december 28-án [9]

\begin{tabular}{lrrrr}
\hline Ország & $\begin{array}{c}\text { A fertőzöttek } \\
\text { száma }\end{array}$ & $\begin{array}{c}\text { A fertőzöttek } \\
\text { száma, PMP }\end{array}$ & $\begin{array}{c}\text { Az } \\
\text { elhunytak } \\
\text { száma }\end{array}$ & $\begin{array}{c}\text { Az } \\
\text { elhunytak } \\
\text { száma, } \\
\text { PMP }\end{array}$ \\
\hline Ausztria & 364574 & 40508,22 & 6253 & 694,78 \\
Belgium & 651567 & 56169,57 & 19776 & 1704,83 \\
Hollandia & 820193 & 47964,50 & 11598 & 678,25 \\
Horvátország & 212958 & 51940,98 & 4072 & 993,17 \\
Luxemburg & 46919 & 78198,33 & 506 & 843,33 \\
Magyarország & 328851 & 33902,16 & 9977 & 1028,56 \\
Németország & 1775513 & 21187,51 & 34574 & 412,58 \\
Szlovénia & 125858 & 59932,38 & 2891 & 1376,67 \\
\hline
\end{tabular}

COVID-19 = koronavírus-betegség 2019; PMP = egymillió lakosra számított adat

Szintén az ECDC adatai alapján a COVID-19 miatt kórházban és intenzív osztályon kezelt betegek számát tudjuk összehasonlítani lakosságszámra súlyozottan az ET tagállamai között. 2020. december 31-én Németország nem közölt adatot a kórházban ellátott COVID19-fertőzöttek számáról; a másik 7 ET-tagállam adatközlése alapján egymillió főre számítva Horvátországban volt a legmagasabb a kórházban kezelt fertőzöttek aránya, a 2. helyen pedig Magyarország szerepelt a tagállamok között [10].

Az intenzív osztályon kezeltek számára vonatkozó adat 6 tagállamból áll rendelkezésre: az intenzív osztályon kezelt COVID-19-fertőzöttek aránya Szlovéniában a legmagasabb egymillió főre viszonyítva [10]. Magyarországról a lélegeztetőgépen lévő COVID-19-fertőzöttek száma áll rendelkezésre: ez 402 beteg volt 2020. december 31-én, vagyis egymillió fơre 41,15 lélegeztetett beteg jutott [5] (2. táblázat) [10].

2. táblázat |A kórházban és intenzív osztályon kezelt COVID-19-fertőzöttek száma az Eurotransplant tagállamaiban 2020. december 31 én [10]

\begin{tabular}{lcccc}
\hline Ország & $\begin{array}{c}\text { Kórházban } \\
\text { kezeltek } \\
\text { száma }\end{array}$ & $\begin{array}{c}\text { Kórházban } \\
\text { kezeltek, } \\
\text { PMP }\end{array}$ & $\begin{array}{c}\text { Intenzív } \\
\text { osztályon } \\
\text { kezeltek } \\
\text { száma }\end{array}$ & $\begin{array}{c}\text { Intenzív } \\
\text { osztályon } \\
\text { kezeltek, } \\
\text { PMP }\end{array}$ \\
\hline Ausztria & 1946 & 216,22 & 396 & 44,00 \\
Belgium & 2187 & 188,53 & 494 & 42,59 \\
Hollandia & 2104 & 123,04 & 724 & 42,34 \\
Horvátország & 2524 & 615,61 & Nincs adat & Nincs adat \\
Luxemburg & 136 & 226,67 & 33 & 55,00 \\
Magyarország & 5856 & 603,71 & Nincs adat & Nincs adat \\
Németország & Nincs adat & Nincs adat & 5623 & 67,10 \\
Szlovénia & 1174 & 559,05 & 195 & 92,86 \\
\hline
\end{tabular}

COVID-19 = koronavírus-betegség 2019; PMP = egymillió lakosra számított adat 


\section{Szervdonációs adatok}

A kórházi koordinátorok bevonásával múködtetett szervdonációs minőségbiztosítási program egyik célja az intézményi szintû szervdonációs potenciál felmérése. Az agykárosodást szenvedett elhunyt betegeket vizsgáljuk, akiknek a felvételi, az eszméletlenséghez vezető vagy a halál okaként megjelölt diagnózisa azon BNO-kódcsoportok egyike, mely a leggyakrabban vezet agyhalál kialakulásához. A jelenleg rendelkezésre álló adatok alapján a kórházi koordinátori intézményekben az agykárosodást szenvedett elhunytak száma és aránya érdemben nem változott, bár intézményenként nagyon jelentős eltérések tapasztalhatók. A 21 intézményben átlagosan 3\%-kal nőtt, míg az összes vizsgálat alá vont elhunyt száma (donoraudit) 7,41\%-kal volt több. Így 2019-ben a 3064 elhunytnál 1468, míg 2020-ban a 3291 elhunytnál 1512 esetben szerepelt agykárosodás a diagnózisok között.

2020-ban 37,30\%-kal (2019: $\mathrm{n}=252 ; 2020: \mathrm{n}=158)$ csökkent a donorjelentések, 38,33\%-kal (2019: $\mathrm{n}=180$; 2020: $\mathrm{n}=111$ ) a megvalósult donációk száma. Az utilizált szervdonorok száma 38,98\%-kal (2019: $\mathrm{n}=177$; 2020: $\mathrm{n}=108$ ) csökkent. Hasonlóan alacsony szervdonációs aktivitás az elmúlt 20 évben nem volt tapasztalható. 1998-ban 125, 1999-ben 117 megvalósult szervdonáció volt Magyarországon. 2020-ban 14\%-kal csökkent a donorjelentó intézmények száma $(2019: \mathrm{n}=50 ; 2020$ : $\mathrm{n}=43)$. 26 intézményben csökkent az elhunyt szervdonorok száma összesen 86 esettel, 67,72\%-kal (2019: n = 127; 2020: $\mathrm{n}=41$ ). A donációs aktivitás 9 kórházban nem változott, 25-25 elhunyt donor volt mindkét évben, további 9 olyan kórházban nem volt szervdonáció 2019 és 2020-ban, ahol korábban igen, és 12 intézményben

3. táblázat | A szervdonációs adatok összehasonlítása 2019-2020-ban

\begin{tabular}{lrrr}
\hline & 2019 & 2020 & Eltérés, \% \\
\hline Szervdonációk elhunytból & 252 & 158 & $-37,30$ \\
Donorjelentések száma & 180 & 111 & $-38,33$ \\
Effektív szervdonorok száma & 177 & 108 & $-38,98$ \\
Utilizált szervdonorok száma & 306 & 174 & $-43,14$ \\
Vesekivételek száma elhunytból & 174 & 117 & $-32,76$ \\
$\quad$ Budapest & 58 & 30 & $-48,28$ \\
$\quad$ Debrecen & 29 & 4 & $-86,21$ \\
$\quad$ Pécs & 45 & 23 & $-48,89$ \\
$\quad$ Szeged & 117 & 69 & $-41,03$ \\
Májkivételek száma & 80 & 47 & $-41,25$ \\
Szívkivételek száma & 6 & 6 & 0,00 \\
Pancreaskivételek száma kombinált & & & \\
beültetésre & 34 & 33 & $-2,94$ \\
Tüdókivételek száma & 543 & 329 & $-39,41$ \\
$\begin{array}{l}\text { A transzplantációs céllal elhunytból } \\
\text { eltávolitott donorszervek száma }\end{array}$ & & & \\
\hline
\end{tabular}

17 esettel, vagyis $60,71 \%$-kal nőtt a szervdonációs aktivitás $(2019: \mathrm{n}=28 ; 2020: \mathrm{n}=45)$.

Az elhunytból történő szervkivételek száma 39,41\%kal (2019: $\mathrm{n}=543 ; 2020: \mathrm{n}=329)$ csökkent. Az egy donorból eltávolított szervek átlagos száma 2020-ban az előző évhez képest 1,75\%-kal (2019: 3,02; 2020: 2,96) csökkent. Az elhunytból történő vesekivételek számának

4. táblázat | A szervtranszplantációs adatok összehasonlítása 2019-2020-ban

\begin{tabular}{|c|c|c|c|}
\hline & 2019 & 2020 & Eltérés, \% \\
\hline \multicolumn{4}{|l|}{ Vese } \\
\hline Veseátültetések száma elbunytból & 236 & 172 & $-27,12$ \\
\hline Budapest & 130 & 92 & $-29,23$ \\
\hline Debrecen & 37 & 27 & $-27,03$ \\
\hline Pécs & 36 & 28 & $-22,22$ \\
\hline Szeged & 33 & 25 & $-24,24$ \\
\hline Élö donoros veseátültetések száma & 30 & 30 & 0,00 \\
\hline Budapest & 23 & 24 & 4,35 \\
\hline Debrecen & 3 & 0 & - \\
\hline Pécs & 4 & 6 & 50,00 \\
\hline Szeged & 0 & 0 & - \\
\hline Szövettanra került donorvese & 16 & 13 & $-18,75$ \\
\hline \multicolumn{4}{|l|}{ Máj } \\
\hline Májtranszplantációk - SE ÁOK & 79 & 50 & $-36,71$ \\
\hline Szövettanra került donormáj & 2 & 1 & $-50,00$ \\
\hline \multicolumn{4}{|l|}{ Szív } \\
\hline Szívtranszplantációk száma összesen & 72 & 45 & $-37,50$ \\
\hline Szívtranszplantációk - SE ÁOK & 64 & 39 & $-39,06$ \\
\hline Szívtranszplantációk - GOKVI & 8 & 6 & $-25,00$ \\
\hline Szövettanra került donorszív & 1 & 1 & 0,00 \\
\hline \multicolumn{4}{|l|}{ Vese és pancreas } \\
\hline $\begin{array}{l}\text { Kombinált vese- és pancreastranszplantá- } \\
\text { ciók száma összesen }\end{array}$ & 5 & 6 & 20,00 \\
\hline $\begin{array}{l}\text { Kombinált vese-pancreas transzplantá- } \\
\text { ció - Budapest }\end{array}$ & 4 & 6 & 50,00 \\
\hline $\begin{array}{l}\text { Kombinált vese-pancreas transzplantá- } \\
\text { ció - Pécs }\end{array}$ & 1 & 0 & $-100,00$ \\
\hline Szövettanra került pancreas & 1 & 1 & 0,00 \\
\hline \multicolumn{4}{|l|}{ Tüdő } \\
\hline Tüdőátültetések száma összesen & 18 & 17 & $-5,56$ \\
\hline Tüdő́átültetés - 'double lung' & 17 & 17 & 0,00 \\
\hline Tüdőátültetés - 'single lung' & 1 & 0 & - \\
\hline $\begin{array}{l}\text { Szövettanra került donortüdő } \\
\text { ( } 1 \text { tüdö }=2 \text { tüdőfél })\end{array}$ & 1 & 0 & - \\
\hline Transzplantált szervek száma (elbunyt) & 410 & 290 & $-29,27$ \\
\hline $\begin{array}{l}\text { Transzplantált szervek száma (elhunyt és } \\
\text { éló donoros) }\end{array}$ & 440 & 320 & $-27,27$ \\
\hline Összes, szövettanra került donorszerv & 21 & 16 & $-23,81$ \\
\hline
\end{tabular}

GOKVI = Gottsegen György Országos Kardiovaszkuláris Intézet; SE ÁOK = Semmelweis Egyetem, Általános Orvostudományi Kar 
csökkenése jelentősen különbözik a 4 vesekivételi régió területén; legkevésbé Budapesten csökkent az aktivitás 32,76\%-kal, míg legnagyobb mértékben a pécsi régióban, 86,21\%-kal. Az életmentő szervátültetési típusokhoz (máj, szív, tüdő) történő donorszerv-kivételek között átlagon felüli a máj- és szívkivételek számának csökkenése, míg a donortüdő-kivételek száma érdemben nem változott 2020-ban a megelőzó évhez képest. A szervkivételi adatokat szervtípusonként a 3. táblázat tartalmazza.

\section{Transzplantációs adatok}

2020-ban 29,27\%-kal, vagyis 120-szal (2019: n = 410; 2020: $n=290)$ kevesebb szervátültetés történt elhunytból, mint 2019-ben. A tüdőátültetések száma alig változott a kétéves összehasonlításban, illetve a veseátültetések számának csökkenése sem érte el a minden szervtípusra jellemző átlagot, ugyanakkor a máj- és szívátültetések száma jelentősen alacsonyabb volt tavaly. A szervátültetési adatokat szervtípusonként a 4. táblázat tartalmazza. A beültetett szervek 29,66\%-a $(\mathrm{n}=86) \mathrm{az}$ ET valamelyik tagállamából érkezett, míg 2019-ben ez az arány $17,32 \%(\mathrm{n}=71)$ volt, vagyis a külföldről kapott szervek száma 21,13\%-kal és aránya 12,34\%-kal emelkedett.

Az élő donoros veseátültetések száma az összehasonlított időszakban nem változott, 30-30 átültetés történt mindkét évben (4. táblázat).

2019-ben egy elhunyt donorból átlagosan 3,02, 2020-ban 2,96 szerv eltávolítása történt. Mivel 2020ban 69-cel kevesebb szervdonor volt Magyarországon, a csökkenés és a 2019. évi donációs aktivitás alapján 208, a 2020. évi aktivitás alapján pedig 204 szervátültetés maradt el a tavalyi évben.

\section{Eurotransplant-adatok}

Az ET egyes tagállamaiban változatos volt az elmúlt év szervdonációs aktivitásának változása. 2020-ban 8,64\%kal csökkent (2019: $\mathrm{n}=1990 ; 2020: \mathrm{n}=1818$ ) az utilizált szervdonorok száma tagállami összesítésben. A kis esetszámok miatt a luxemburgi donációs aktivitáson kívül a csökkenés Magyarországon volt a legnagyobb mértékü a tagállamok között (5. táblázat).

\section{Európai adatok}

A 27 EU-tagállam és az Egyesült Királyság donációs adatainak feldolgozását 22 adatközlő EU-tagállam és az Egyesült Királyság adatszolgáltatása alapján végeztük [11]. 2019-ben a 23 adatközlő országban összesen 11154 (21,66 PMP), 2020-ban 9184 (18,14 PMP) elhunyt szervdonor volt, ez 17,66\%-os csökkenést jelent az előző évhez képest. A 23 országból 5 tagállamban emelkedett a donációs aktivitás, 18 tagállamban csök-
5. táblázat |Az utilizált szervdonorok száma 2019-2020-ban az Euro transplant tagállamaiban

\begin{tabular}{lrrrrr}
\hline ET-tagországok & 2019 & $\begin{array}{c}2019, \\
\text { PMP }\end{array}$ & 2020 & $\begin{array}{c}2020, \\
\text { PMP }\end{array}$ & $\begin{array}{c}\text { Eltérés, } \\
\%\end{array}$ \\
\hline Ausztria & 180 & 20,45 & 188 & 20,89 & 4,44 \\
Belgium & 312 & 26,9 & 245 & 21,21 & $-21,47$ \\
Hollandia & 250 & 14,62 & 251 & 14,68 & 0,40 \\
Horvátország & 128 & 31,22 & 97 & 23,66 & $-24,22$ \\
Luxemburg & 5 & 8,33 & 3 & 5,00 & $-40,00$ \\
Magyarország & 178 & 18,35 & 107 & 11,03 & $-39,89$ \\
Németország & 899 & 10,91 & 888 & 10,60 & $-1,22$ \\
Szlovénia & 38 & 18,10 & 39 & 18,57 & 2,63 \\
\hline
\end{tabular}

ET = Eurotransplant; PMP = egymillió lakosra számított adat

kent. A donorszám változásának mértéke szerint csökkenő sorrendbe helyezett 23 tagállam között Magyarország a 20. helyen szerepel.

Ha Magyarországon is olyan mértékben csökkent volna a donációs aktivitás, mint az EU-ban átlagosan, akkor 148 elhunyt donor lett volna hazánkban. Azon országok közül, ahol nőtt a donációs aktivitás, a legnagyobb mértékû növekedés Észtországban volt: $32 \%$ (2019: $\mathrm{n}=25$; 2020: n = 33), a legkisebb mértékú növekedést pedig két ET-tagállamban, Szlovéniában: 6,82\% (2019: n = 44; 2020: $\mathrm{n}=47$ ) és Ausztriában: 0,49\% (2019: $\mathrm{n}=206$; 2020: n = 207) mérték. Azon országok közül, ahol csökkenés volt tapasztalható, a legnagyobb mértékú csökkenés a kis esetszámú Máltán volt: 80\% (2019: n = 10; 2020: $n=2$ ), a legkisebb mértékü csökkenés pedig a szintén az ET-hoz tartozó Hollandiában: 1,16\% (2019: $\mathrm{n}=258 ; 2020: \mathrm{n}=255)$. Magyarország a csökkenő aktivitással rendelkező 18 ország között a 15 . helyen szerepel az aktivitáscsökkenés mértékének súlyossága tekintetében, a sorrendben hazánk után következő országok azonban mind kifejezetten alacsony, 20 alatti éves donációs esetszámmal bírnak [11].

\section{Várólistaadatok}

2020-ban 25\%-kal kevesebb új beteget regisztráltak, mint 2019-ben (2019: $\mathrm{n}=612 ; 2020: \mathrm{n}=461$ ), és $5 \%$ kal kevesebb beteg (2019: $\mathrm{n}=2002 ; 2020$ : $\mathrm{n}=1893$ ) fordult meg hazai transzplantációs várólistákon. A várólista-mortalitás 28\%-kal növekedett az előzó évhez képest (2019: n = 83; 2020: n = 106), leginkább a veseátültetésre várók között. A részletes adatokat szervtípusonként a 6. táblázatban mutatjuk be.

\section{Következtetés}

Az új típusú koronavírus okozta járvány közvetett hatása a szervadományozás és -átültetés területén is megjelent világszerte, így Magyarországon is. Ez a szervdonációs 
6. táblázat |A transzplantációs várólisták adatai 2019-ben és 2020-ban

\begin{tabular}{|c|c|c|c|c|c|c|c|c|c|c|c|c|}
\hline \multirow{3}{*}{ A szerv típusa } & \multicolumn{4}{|c|}{ A regisztrált új betegek száma } & \multicolumn{4}{|c|}{ A várólistán megfordult betegek száma } & \multicolumn{4}{|c|}{ Várólista-halálozás } \\
\hline & \multirow[t]{2}{*}{2019} & \multirow[t]{2}{*}{2020} & \multicolumn{2}{|c|}{ Eltérés } & \multirow[t]{2}{*}{2019} & \multirow[t]{2}{*}{2020} & \multicolumn{2}{|c|}{ Eltérés } & \multirow[t]{2}{*}{2019} & \multirow[t]{2}{*}{2020} & \multicolumn{2}{|c|}{ Eltérés } \\
\hline & & & $\mathrm{n}$ & $\%$ & & & $\mathrm{n}$ & $\%$ & & & $\mathrm{n}$ & $\%$ \\
\hline Vese & 368 & 285 & -83 & -23 & 1519 & 1460 & -59 & -4 & 43 & 72 & 29 & 67 \\
\hline Máj & 113 & 90 & -23 & -20 & 195 & 180 & -15 & -8 & 19 & 18 & -1 & -5 \\
\hline Szív & 96 & 65 & -31 & -32 & 184 & 168 & -16 & -9 & 10 & 11 & 1 & 10 \\
\hline Tüdő & 31 & 14 & -17 & -55 & 45 & 32 & -13 & -29 & 4 & 2 & -2 & -50 \\
\hline Vese és pancreas & 4 & 7 & 3 & 75 & 57 & 51 & -6 & -11 & 7 & 3 & -4 & -57 \\
\hline Pancreas & 0 & 0 & 0 & - & 2 & 2 & 0 & 0 & 0 & 0 & 0 & - \\
\hline Összesen & 612 & 461 & -151 & -25 & 2002 & 1893 & -109 & -5 & 83 & 106 & 23 & 28 \\
\hline
\end{tabular}

folyamat minden lépésénél akadályt jelenthetett, így a donorfelismerésnél, -jelentésnél, -gondozásnál, -alkalmasságnál, a végstádiumú betegeknek a várólistára helyezéshez és a listán tartáshoz szükséges kivizsgálásánál, valamint a szervkivételeknél és -átültetéseknél is.

Az Országos Vérellátó Szolgálat és az Egészségügyi Szakmai Kollégium Transzplantáció Tagozata által az új típusú koronavírussal kapcsolatban először márciusban kiadott szervdonációs eljárásrend célja a szervdonációs folyamat minőségének és biztonságának megőrzése a recipiensek és az egészségügyi dolgozók védelme érdekében. Világszerte új kihívást jelentett egy korábban ismeretlen kórokozó járványos terjedése mellett a donoreredetű fertőzésnek, továbbá a transzplantációs ellátás során is a recipiensek fertőzésének megelőzése. Ez különös jelentőséggel bír egy immunszuppresszív terápiában részesülő, sérülékeny betegcsoport esetén. Az eljárásrend folyamatos aktualizálásával követtük a nemzetközi ajánlásokat, és alkalmazkodtunk a járvány terjedéséhez; a 2020. év végén a 17. verzió volt hatályban. Ebben a donorok szürését, a kockázatfelmérés kötelező elemeit, a PCR-vizsgálat rendjét és a mintavételt, valamint a szervkivételekre vonatkozó biztonsági szempontokat szabályoztuk. A hazai szabályozás és annak szigorú alkalmazása eredményesnek bizonyult, donoreredetű átvitel nem történt hazánkban. A felismert és jelentett potenciális szervdonorok között 2020-ban 7 olyan eset volt, amelynek során a szervkivétel igazolt COVID-19-infekció vagy annak gyanúja miatt hiúsult meg. Eddig l külföldi közlemény jelent meg donoreredetű SARS-CoV-2-átvitelről tüdőátültetéshez kapcsolódóan, amelynél nem végeztek RT-PCR-vizsgálatot alsó légúti mintából [12]. Nincs evidencia a SARS-CoV-2 esetében donor-recipiens-átvitelről más szervtípusok esetén.

A szervdonációs aktivitás a kórházi ellátórendszer egyik legérzékenyebb és leggyorsabban reagáló indikátora. A járvány miatt fokozatosan egyre nagyobb teher jelentkezett a kórházi és intenzív osztályos ellátást igénylő betegek miatt. Mindemellett az ET-tagállamokban az országonként egymillió lakosra jutó COVID-19-fertőzöttek és -halálozások száma nem igazolja önmagában a hazai szervdonációs aktivitás ilyen mértékű csökkenését, miközben a súlyos agykárosodás miatt elhunyt betegek száma nem csökkent, és így a donációs potenciál sem. Érdekes ugyanakkor, hogy az első hullám idején Spanyolországban a donorszám 83\%-kal, az átültetések száma 87\%-kal csökkent [13]. UNOS-közlemény alapján az Egyesült Államokban az első hullám idején 45\%-kal csökkent az elhunyt szervdonorok száma [14], 36\%-kal a transzplantációs aktivitás, 23\%-kal az új betegek száma a várólistán, és 26\%-kal emelkedett a várólista-mortalitás [15]. Az Egyesült Királyságban 66\%-kal volt alacsonyabb az elhunyt donorok száma idén márciustól májusig, mint az előzô év azonos periódusában [16]. Ez azt jelenti egyrészt, hogy a járvány által először sújtott országokban drasztikus, de átmeneti csökkenés mutatkozott a szervdonációk számában. Továbbá azokban az országokban zuhant nagyobb mértékben a donációs aktivitás, ahol kiemelkedő volt előtte.

A szervátültetések száma nem csökkent olyan mértékben, mint a donorok száma, ami elsősorban annak köszönhető, hogy az Eurotransplant Nemzetközi Szervcsere Szervezet keretei között több donorszerv érkezett hazánkba, mint amennyit külföldre küldtünk, és több donorszerv érkezett 2020-ban, mint a megelőzó évben. Ez a körülmény kedvezően befolyásolta a magyar betegek donorszervhez jutási esélyeit a járvány megjelenésének évében. A 4 centrumban végzett veseátültetések tekintetében nincs jelentős különbség a centrumok aktivitásának egymáshoz viszonyított változásában (4. táblázat), ami egyrészt az országosan egységes allokációs rendszernek, a szervelosztási algoritmusban alkalmazott pontozásnak és így esélyegyenlőségnek, másrészt a centrumok egymáshoz hasonló, biztonságos döntési szempontrendszerének köszönhető.

Kevesebb végstádiumú szervelégtelen beteg került transzplantációs várólistára, főleg a tüdőre és a szívre várakozók közé 2020-ban. Érdekes összefüggés, hogy az új betegek számának csökkenése nagyobb mértékú volt, mint a transzplantáció miatt a várólistáról lekerülő betegek számának csökkenése 1 év elteltével. Ennek következtében a várólistán megfordult betegek száma is csök- 
kent. A kisebb betegszám ellenére viszont nőtt a várólista-mortalitás.

A már kontroll alatt tartott, járvány utáni időszak egyik legnagyobb kihívása a szervdonációs programok visszaállítása lesz a szervdonációs potenciál által adott lehetőséghez mérten. Addig is minden agyhalott szerveit ki kell menteni, ha van kapacitás, és nincs átvihető fertőzés, továbbá minden felajánlott donorszervet egyedileg kell értékelni, de transzplantálni kell, ha az átültetés feltételei adottak. A betegeket el kell juttatni a várólistáig, és utána meg kell menteni őket a listáról.

Anyagi támogatás: A közlemény megírása anyagi támogatásban nem részesült.

Szerzői munkamegosztás: M. S.: A vizsgálat céljának, tárgyának és módszerének kidolgozása, adatgyưjjés, az eredmények rögzítése, az eredmények értékelése, statisztikai elemzés, a kézirat szövegezése. E.-V. A.: Adatgyüjtés, irodalomkutatás. T.-Sz. K.: Adatgyüjtés, irodalomkutatás. D. O.: Adatgyưjtés, az eredmények értékelése. H. E.: Adatgyưjtés. N. J.: A kézirat szövegezése. P. L.: Az eredmények értékelése, a kézirat szövegezése. A cikk végleges változatát valamennyi szerző elolvasta és jóváhagyta.

Érdekeltségek: A szerzőknek nincsenek érdekeltségeik.

\section{Köszönetnyilvánítás}

A szerzők ezúton fejezik ki köszönetüket a cikk megírása során kapott támogatásért.

\section{Irodalom}

[1] Wang D, Hu B, Hu C, et al. Clinical characteristics of 138 hospitalized patients with 2019 novel coronavirus-infected pneumonia in Wuhan, China. JAMA 2020; 323: 1061-1069. [Erratum: JAMA 2021; 325: 1113.]

[2] Zhu N, Zhang D, Wang W, et al. A novel coronavirus from patients with pneumonia in China, 2019. N Engl J Med. 2020; 382: 727-733.

[3] John Hopkins University of Medicine. Coronavirus Resource Center. Available from: https://coronavirus.jhu.edu/map.html [accessed: March 17, 2021].

[4] World Health Organization. WHO Director-General's opening remarks at the media briefing on COVID-19 - March 2020.
Available from: https://www.who.int/dg/speeches/detail/ who-director-general-s-opening-remarks-at-the-media-briefingon-covid-19---20-march-2020 [accessed: March 17, 2021].

[5] National Public Health Center. Information site about the coronavirus. [Nemzeti Népegészségügyi Központ. Tájékoztató oldal a koronavírusról.] Available from: http://koronavirus.gov.hu [accessed: March 17, 2021]. [Hungarian]

[6] Loupy A, Aubert O, Reese PP, et al. Organ procurement and transplantation during the COVID-19 pandemic. Lancet 2020; 395: e95-e96.

[7] Fishman JA, Grossi PA. Novel coronavirus-19 (COVID-19) in the immunocompromised transplant recipient: flattening the curve. Am J Transplant. 2020; 20: 1765-1767.

[8] Coll E, Fernández-Ruiz M, Sánchez-Álvarez JE, et al. COVID-19 in transplant recipients: the Spanish experience. Am J Transplant. 2020 Oct 23. Doi: 10.1111/ajt.16369. [Epub ahead of print]

[9] European Centre for Disease Prevention and Control. Data on 14-day notification rate of new COVID-19 cases and deaths. Available from: https://www.ecdc.europa.eu/en/publicationsdata/data-national-14-day-notification-rate-covid-19 [accessed: March 17, 2021].

[10] European Centre for Disease Prevention and Control. Data on hospital and ICU admission rates and current occupancy for COVID-19. Available from: https://www.ecdc.europa.eu/en/ publications-data/download-data-hospital-and-icu-admissionrates-and-current-occupancy-covid-19 [accessed: March 17, 2021].

[11] Global Observatory on Donation and Transplantation. Export database. Available from: http://www.transplant-observatory. org/export-database/ [accessed: March 17, 2021].

[12] Kaul DR, Valesano AL, Petrie JG, et al. Donor to recipient transmission of SARS-CoV-2 by lung transplantation despite negative donor upper respiratory tract testing. Am J Transplant. 2021 Mar 28. Doi: 10.1111/ajt.16532. [Epub ahead of print]

[13] Domínguez-Gil B, Coll E, Fernández-Ruiz M, et al. COVID-19 in Spain: transplantation in the midst of the pandemic. Am J Transplant. 2020; 20: 2593-2598.

[14] Goff RR, Wilk AR, Toll AE, et al. Navigating the COVID-19 pandemic: initial impacts and responses of the Organ Procurement and Transplantation Network in the United States. Am J Transplant. 2020 Nov 26. Doi: 10.1111/ajt.16411. [Epub ahead of print]

[15] Cholankeril G, Podboy A, Alshuwaykh OS, et al. Early impact of COVID-19 on solid organ transplantation in the United States. Transplantation 2020; 104: 2221-2224.

[16] Manara AR, Mumford L, Callaghan CJ, et al. Donation and transplantation activity in the UK during the COVID-19 lockdown. Lancet 2020; 396: 465-466.

(Mihály Sándor dr., Budapest, Karolina út 19-21., 1113 e-mail: mihaly.sandor@ovsz.hu)

\footnotetext{
A cikk a Creative Commons Attribution 4.0 International License (https://creativecommons.org/licenses/by-nc/4.0/) feltételei szerint publikált Open Access közlemény, melynek szellemében a cikk bármilyen médiumban szabadon felhasználható, megosztható és újraközölhető, feltéve, hogy az eredeti szerző és a közlés helye, illetve a CC License linkje és az esetlegesen végrehajtott módositások feltüntetésre kerülnek.
} 